\title{
ПРОДУКТИВНІСТЬ КНУРІВ ЗАРУБІЖНОГО ПОХОДЖЕННЯ
}

\author{
Рецензент - доктор сільськогосподарських наук, професор А. А. Поліщук
}

Наведені результати досліджень щзодо оиінки якості сперми кнурів великої білої породи, дюрок, ландрас $i$ n'єтрен німецької селекиії, а також відтворювальної здатності свиноматок великої білої породи й ландрас франиузького походження за схрещування із вищзевказаними кнурами німецького походження. Встановлена суттєва різничя за концентрацією, об'ємом та активністю сперми у кнурів німецького походження як у залежності від породи, так і сезону року. Найбільш відчутно ефект гетерозису за багатоплідністю проявлясться при схрещуванні маток великої білої породи франиузької селекції з кнурами великої білої породи німецької селекиії.

Ключові слова: свині, походження, якість сперми, відтворювальна здатність.

Постановка проблеми. Останні роки в Україні поряд із вітчизняними чи адаптованими до різних еколого-природних зон 12-ма породами свиней використовують генотипи зарубіжного походження, які відселекціоновані здебільшого за певними ознаками продуктивності. Свиноматки і кнури імпортованого поголів'я використовуються в умовах племінних господарств для чистопородного розведення чи ввідного схрещування, а у промислових - схрещування й гібридизації з метою одержання ефекту гетерозису у відгодівельного поголів'я $[1,3,11]$.

Відтворення свиней за інтенсивного використання методу штучного осіменіння змушує 3 особливою вимогливістю ставитися до кнурівплідників: їх довголіття, статева активність, якість спермопродукції залежать від низки чинників, зокрема породи, успадковуваності ознак, методів вирощування, рівня годівлі й утримання тощо. Неузгодженість даних гено- та паратипових чинників може нанести галузі свинарства досить суттєвих збитків.

Наукові дані й накоплений досвід розведення свиней вказує, що одним із перспективних способів підвищення продуктивності тварин $є$ міжпородне схрещування та гібридизація, які дають змогу більш повно використовувати генетичні можливості батьківської і материнської порід.
Помісні тварини зазвичай перевищують чистопородних за приростом живої маси, витратами корму, виходом м'яса в туші тощо $[6,8]$.

Максимальний ефект при схрещуванні і гібридизації можна отримати тільки поєднуючи тварин з однаково високими м'ясними і відгодівельними якостями. Підвищення відтворювальної здатності відбувається за схрещування двохчотирьох порід різного напряму продуктивності. Найбільш перспективними є використання порід йоркшир, ландрас і п'єтрен; можливе також використання порід дюрок і гемпшир [13].

Із урахуванням вищевикладеного актуальним було й залишається питання одержання високої продуктивності свиней за схрещування. При цьому першочерговим завданням $€$ контролювання якості сперми кнурів і використанням у результаті відтворення тих із них, які мають високу концентрацію та активність сперміїв з урахуванням періоду року.

Аналіз останніх досліджень і публікацій, у яких започатковано розв'язання проблеми. Аналіз стану розвитку свинарства у більшості країн світу за останні роки свідчить, що в галузі широкого застосування набули наукові досягнення 3 технології відтворення та селекції, які забезпечують постійне зростання виробництва продукції й покращання іiі якості .

Відомо, що кнури, навіть однієї породи, різняться за власними біологічними ознаками і неоднаково впливають на показники продуктивності одержаного від них потомства. Чисельні дослідження свідчать, що при оцінці кнурів за генотипом лише 20-25 \% їх є поліпшувачами, стільки ж погіршувачів, а решта - нейтральні [9].

Оцінка кнурців різних порід, вирощених в умовах елеверу, вказує на їх різну якість як за живою масою і довжиною тіла, так і запліднюючою здатністю сперми. Запліднююча здатність сперми у кнурів полтавської м'ясної породи становила 92,5 \%, червонобілопоясної - 88,4 \%, миргородської - 88,4 \%, великої білої - 84,4 \%, ландрас $-84,7$ \% і дюрок - 80,3 \% [10].

* Науковий керівник - доктор сільськогосподарських наук С. Л. Войтенко 
Доведено, що кнури білоруської м'ясної й великої білої порід, вирощені за середньої інтенсивності росту, перевищували ровесників як із меншою інтенсивністю росту, так і вищою за об'ємом еякуляту, концентрацією сперми, запліднюючою здатністю та багатоплідністю маток. Підвищена відтворювальна здатність обгрунтовувалася дією ефекту формоутворюючих процесів під час вирощування, що позитивно вплинула на якісні показники спермопродукції кнурів, вирощених саме за середнього рівня середньодобових приростів [12].

При оцінці кнурів різних порід данської селекції встановлена сезонна варіабельність спермопродукції навіть у межах однієї породи. Об'єм еякуляту здебільшого залежав від породи, а не сезону року [7].

Відтворювальна здатність кнурів-плідників відноситься до основних чинників якісного удосконалення стада та підвищення рентабельності галузі [5].

На доцільність використання внутрішньопородних поєднань свиней великої білої породи, української, естонської, англійської та німецької селекції для підвищення господарськи корисних ознак вказано в роботі [2]. За результатами досліджень встановлено, що найбільш ефективними виявилися поєднання свиноматок великої білої породи української селекції з кнурами великої білої породи естонської та англійської селекції.

Поєднання свиноматок великої білої породи англійської селекції з кнурами цієї ж породи данської та французької селекції дало змогу встановити, що для підвищення багатоплідності на 0,87 голів та молочності на 2,4 кг кращими $€$ поєднання генотипів велика біла англійської селекції з великою білою данської селекції [4].

Отже, огляд літературних джерел щодо ефективності використання методів схрещування для одержання додаткової продукції не залишає сумнівів стосовно актуальності й практичного значення впровадження такого методу розведення свиней у виробництво, як і найбільш продуктивних поєднань та сучасних методів підбору батьківських генотипів.

Мета досліджень полягала у пошуку кращих варіантів схрещування свиней зарубіжних генотипів для одержання більшої кількості поросят при народженні та їх кращої збереженості.

Матеріали та методи досліджень. Дослідження проведені в умовах Прилуцького племпідприємства та ТОВ «Агрікор-Холдинг» Чернігівської області. У першому досліді вивчалась якість сперми кнурів німецького походження порід велика біла (I група - контрольна), дюрок (II група - дослідна), ландрас (III група - дослідна) і п'єтрен (IV група - дослідна). Сперму в кнурів отримували на штучну вагіну двічі на тиждень в одноразові спермоприймачі. Якість сперми вивчали за її об'ємом, концентрацією та рухливістю. Для визначення кращих варіантів поєднуваності свиней спеціалізованих генотипів зарубіжної селекції за відтворювальною здатністю був проведений другий дослід, за якого свиноматок великої білої породи (ВБФП) та ландрас (ЛФП) французького походження осіменяли спермою кнурів порід велика біла (ВБНП), дюрок (ДНП), ландрас (ЛНП) і п'єтрен (ПНП) німецького походження. Відтворювальну здатність вивчали за багатоплідністю, великоплідністю, збереженістю поросят, масою гнізда та однієї голови при відлученні у 28-денному віці.

Результати досліджень. Оцінка концентрації сперматозоїдів дає змогу зробити висновок про вплив на неї як породи, так і сезону року. Взимку, влітку і восени найвищою концентрацією сперматозоїдів в еякуляті характеризувалася сперма кнурів породи дюрок, відповідно, 510,3; 469,0 і 483,7 млн/мл, навесні п'єтрен - 521,1 млн/мл. Серед досліджуваних порід на протязі року найменшу концентрацію сперматозоїдів в еякуляті (408,8 - 344,8 млн/мл) мали кнури породи ландрас. До того ж у кнурів даного генотипу найменша концентрація сперматозоїдів в еякуляті відмічена влітку. Стабільною за концентрацією протягом року була сперма кнурів великої білої породи, що вказує на можливість одержання однакової кількості спермодоз незалежно від пори року. Кнури різних порід на протязі року мали не однаковий об'єм еякуляту. Від кнурів великої білої породи найбільший об'єм еякуляту одержали влітку - 307,8 мл, а найменший взимку - 243,7 мілілітрів. У кнурів породи дюрок даний показник упродовж року варіював у межах 204,5-237,4 мл за найвищого значення влітку. Кнури породи ландрас весною і влітку мали найвищий об'єм еякуляту (327,5-343,0 мл) за поступового зниження його до зими. Особливістю кнурів породи п'єтрен був найменший із-поміж досліджуваних генотипів об'єм еякуляту в різні пори року. При цьому найвищим даний показник у них був влітку - 204,1 мілілітрів.

На протязі року найвищою активністю характеризувалася сперма кнурів породи дюрок (8,8-8,3 бали) за найвищої їі активності в зимовий і літній періоди. Для кнурів порід велика біла і п'єтрен не встановлено сезонного впливу 
Відтворювальна здатність свиноматок при схрещуванні

\begin{tabular}{|c|c|c|c|c|c|c|c|}
\hline $\begin{array}{l}\text { Піддос- } \\
\text { лідні } \\
\text { групи }\end{array}$ & $\begin{array}{c}\text { Призначення } \\
\text { груп }\end{array}$ & $\begin{array}{c}\text { Поєднання } \\
\text { порід }\end{array}$ & $\begin{array}{c}\text { Багато- } \\
\text { плідність, } \\
\text { гол. }\end{array}$ & $\begin{array}{c}\text { Велико- } \\
\text { плідність, } \\
\text { кг }\end{array}$ & $\begin{array}{l}\text { К-сть поро- } \\
\text { сят при від- } \\
\text { лученні, } \\
\text { гол. } \\
\end{array}$ & $\begin{array}{c}\text { Маса гніз- } \\
\text { да поросят } \\
\text { при відлу- } \\
\text { енні, кг }\end{array}$ & $\begin{array}{c}\text { Середня маса } \\
\text { однієї голови } \\
\text { при відлучен- } \\
\text { ні, кг } \\
\end{array}$ \\
\hline I & контрольна & $\begin{array}{c}\text { ВБФП x } \\
\text { ВБНП }\end{array}$ & $\begin{array}{c}11,2 \pm \\
0,42\end{array}$ & $\begin{array}{l}1,2 \pm \\
0,03\end{array}$ & $\begin{array}{c}10,2 \pm \\
0,39\end{array}$ & $\begin{array}{c}79,9 \pm \\
4,97\end{array}$ & $\begin{array}{l}7,9 \pm \\
0,42 \\
\end{array}$ \\
\hline II & дослідна & $\begin{array}{l}\text { ВБФП x } \\
\text { ДНП }\end{array}$ & $\begin{array}{c}9,2 \pm \\
0,42 * *\end{array}$ & $\begin{array}{c}1,4 \pm \\
0,02 * * *\end{array}$ & $\begin{array}{c}8,7 \pm \\
0,33^{* *}\end{array}$ & $\begin{array}{c}77,7 \pm \\
4,55 \\
\end{array}$ & $\begin{array}{c}9,1 \pm \\
0,34^{*}\end{array}$ \\
\hline III & дослідна & $\begin{array}{l}\text { ВБФП x } \\
\text { ЛНП }\end{array}$ & $\begin{array}{c}11,1 \pm \\
0,57\end{array}$ & $\begin{array}{c}1,1 \pm \\
0,04 * *\end{array}$ & $\begin{array}{l}9,6 \pm \\
0,31 \\
\end{array}$ & $\begin{array}{c}80,4 \pm \\
5,64\end{array}$ & $\begin{array}{c}9,0 \pm \\
0,34^{*}\end{array}$ \\
\hline IV & дослідна & $\begin{array}{c}\text { ВБФП x } \\
\text { ПНП }\end{array}$ & $\begin{array}{c}9,6 \pm \\
0,60^{*}\end{array}$ & $\begin{array}{c}1,4 \pm \\
0,02 * * *\end{array}$ & $\begin{array}{l}9,0 \pm \\
0,44\end{array}$ & $\begin{array}{c}76,6 \pm \\
4,87 \\
\end{array}$ & $\begin{array}{l}8,6 \pm \\
0,44\end{array}$ \\
\hline $\mathrm{V}$ & дослідна & $\begin{array}{l}\text { ЛФП x } \\
\text { ВБНП } \\
\end{array}$ & $\begin{array}{c}11,7 \pm \\
0,42 \\
\end{array}$ & $\begin{array}{l}1,2 \pm \\
0,03 \\
\end{array}$ & $\begin{array}{l}9,7 \pm \\
0,42 \\
\end{array}$ & $\begin{array}{c}69,1 \pm \\
6,12 \\
\end{array}$ & $\begin{array}{l}7,0 \pm \\
0,38\end{array}$ \\
\hline VI & дослідна & $\begin{array}{c}\text { ЛФП x } \\
\text { ДНП }\end{array}$ & $\begin{array}{c}9,9 \pm \\
0,31 *\end{array}$ & $\begin{array}{c}1,3 \pm \\
0,02 * * *\end{array}$ & $\begin{array}{c}8,9 \pm \\
0,18^{* *}\end{array}$ & $\begin{array}{c}74,2 \pm \\
3,57 \\
\end{array}$ & $\begin{array}{c}9,0 \pm \\
0,34^{*}\end{array}$ \\
\hline VII & дослідна & $\begin{array}{c}\text { ЛФП x } \\
\text { ЛНП }\end{array}$ & $\begin{array}{c}10,6 \pm \\
0,88\end{array}$ & $\begin{array}{c}1,3 \pm \\
0,03 * *\end{array}$ & $\begin{array}{l}9,3 \pm \\
0,56\end{array}$ & $\begin{array}{c}74,3 \pm \\
6,29\end{array}$ & $\begin{array}{l}8,0 \pm \\
0,43\end{array}$ \\
\hline VIII & дослідна & $\begin{array}{c}\text { ЛФП x } \\
\text { ПНП }\end{array}$ & $\begin{array}{c}10,9 \pm \\
0,53\end{array}$ & $\begin{array}{c}1,2 \pm \\
0,04 * * *\end{array}$ & $\begin{array}{l}9,6 \pm \\
0,43\end{array}$ & $\begin{array}{c}79,6 \pm \\
4,37\end{array}$ & $\begin{array}{l}8,3 \pm \\
0,22\end{array}$ \\
\hline
\end{tabular}

Примітка: $* \mathrm{P}<0,05 ; * * \mathrm{P}<0,01 ; * * * \mathrm{P}<0,001$

на активність сперматозоїдів за незначної варіабельності показника. Характерною особливістю кнурів породи ландрас була майже однакова впродовж року невисока, порівняно 3 іншими породами, активність сперми (7, 8-7,6 балів).

Результати наших досліджень із визначення ефективності схрещування свиней спеціалізованих м'ясних генотипів зарубіжної селекції дали змогу стверджувати, що найбільш відчутно ефект гетерозису за багатоплідністю проявився при поєднанні маток породи ландрас французької селекції з кнурами великої білої породи німецької селекції - 11,7 голів (див. табл.).

Свиноматки контрольної групи за даним показником перевищували маток усіх піддослідних груп (за виключенням V дослідної групи). Найменшою кількістю живих поросят при народженні характеризувалися матки великої білої породи при схрещуванні з кнурами порід дюрок і п'єтрен (9,2-9,6 голів), а матки породи ландрас - при підборі з кнурами породи дюрок - 9,9 голів. Така ситуація ймовірно узгоджується 3 породною особливістю генотипів та поєднуваністю вихідних батьківських порід, у результаті чого не одержано суттєвого підвищення багатоплідності навіть при схрещуванні.

Великоплідність поросят у наших дослідженнях залежала від їх кількості при народженні й була найвищою у маток тих груп, які мали невисоку багатоплідність (9,2-9,9 голів).
Згідно 3 одержаними даними, кількість поросят до відлучення варіювала від 8,7 до 10,2 голів. Найбільша жива маса гнізда поросят при відлученні характерна для маток III і VIII дослідних та контрольної груп, відповідно, 80,4; 79,6 та 79,9 кілограм.

Свиноматки контрольної групи переважали за середньою живою масою однієї голови поросят при відлученні у 28 днів на 0,9 кг лише тварин $\mathrm{V}$ дослідної групи (ЛФП х ВБНП), але поступалися на $0,1-1,2$ кг маткам інших дослідних груп.

У дослідженнях встановлена тенденція впливу кнурів породи дюрок і п'єтрен на великоплідність та середню живу масу однієї голови при відлученні, що узгоджується 3 даними інших дослідників. Відчутного впливу породи свиноматок на багатоплідність й інші показники відтворювальної здатності не виявлено.

\section{Висновки:}

1. Кнури спеціалізованих порід німецької селекції характеризувалися значною варіабельністю спермопродукції протягом року, особливо об'єму еякуляту та концентрацією сперматозоїдів, що впливало на кількість і якість одержаної від них продукції. Ймовірно, для підвищення запліднюючої здатності кнурів даних генотипів найкраще використовувати змішану сперму або чітко враховувати особливості кожного кнура щодо якості й кількості сперми за сезонами року.

2. Для одержання високої багатоплідності та 
збереженості поросят в умовах промислових господарств доцільно схрещувати маток великої білої породи французького походження з кнурами великої білої породи німецького походження,

\section{БІБЛІОГРАФІЯ}

1. Аниховская И. В. Влияние хряков импортных пород на откормочные и мясосальные качества помесного молодняка / И. В. Аниховская // Современные проблемы интенсификации производства свинины : Международной науч.-практ. конф., 11-13 июля 2007 г. : тезисы докл. Ульяновск, 2007. - Т. 1. - С. 91-97.

2. Ващенко П. А. Вивчити внутріпородні поєднання генотипів свиней великої білої породи вітчизняної та зарубіжної селекції на етапі закладки нових генеалогічних структур : автореф. дис. ... канд. с.-Г наук : спец. 06.02.01 «Розведення і селекція тварин» / П. А. Ващенко. - Полтава, 2005. $-22 \mathrm{c}$.

3. Кабанов В. Д. Эффективный способ повышения мясной продуктивности свиней / В. Д. Кабанов, А. Н. Бетин // Зоотехния. - 2010. - № 1. C. $22-24$.

4. Луговий С. I. Відтворювальна здатність свиноматок великої білої породи англійської селекції / С. І. Луговий // Аграрний вісник Причорномор'я. - 2005. - Вип. 31. - С. 44-45.

5. Казаниева Н. П. Контрольное выращивание и оценка хряков на элевере / Н. П. Казанцева, Е. С. Маринина // Современны проблемы интенсификации производства свинины в странах СНГ: сб. научн. тр. XVII Международной науч.практ. конф. по свиноводству. - Ульяновск, 2010. - T. 2. - C. 175-180.

6. Мглинеи A. А. Повышение продуктивності маточного стада свиней в товарном хозяйстве / А. А. Мглинец, С. С, Данч, И. В. Гусев // Свиноводство. -2010 . - № 1. - С. 34-35.

7. Олексисвич E. А. Сезонные показатели качества спермы хряков разных пород датской селек- а також маток породи ландрас французького походження 3 кнурами великої білої породи i п’єтрен німецького походження.

ции в условиях Ленинградской области / Е. А. Олексисвич, Л. Г. Мороз //Пути интенсификации отрасли свиноводства в странах СНГ : сб. тр. XVI Международной науч.-практ. конф. Гродно, 2009. - С. 88-89.

8. Рибалко В. П. Оцінка кнурів-плідників за якістю потомства / В.П. Рибалко // Свиноводство. 1990. - № 3. - C. 10-12.

9. Рибалко В. П. Якісні особливості кнурів різних генотипів, вирощених в умовах елевера / В. П. Рибалко, А. Н. Оксенюк // Свинарство. К. : Аграрна наука, 1993. - Вип. 54. - С. 3-9.

10. Рибалко В. П. Стратегічні аспекти ведення галузі свинарства у кризовий період / В. П. Рибалко, А. А. Гетя // Науковий вісник НУ біоресурсів і природокористування України. - К, 2009. - Вип. 138. - С. 133-137.

11. Федоренкова Л. А. Влияние хрякав импортных генотипов на качество свиней / Л. А. Федоренкова, Е. А. Янович, Т. В. Батковская // Зоотехнічна наука Поділля: історія, проблеми, перспективи: Міжнародної наук.-практ. конф. Кам'янець-Подільський, 2010. - С. 281-283.

12. Шаиякий М. А. Породные особенности влияния интенсивности роста хряков на селекционно-генетические параметры показателей воспроизводства / М. А. Шацкий // Современны проблемы интенсификации производства свинины в странах СНГ: сб. научн. тр. XVII Международной науч.-практ. конф. по свиноводству. - Ульяновск, 2010. - Т. 2. - С. 351-358.

13. Соколов $H$. Перспективы использования генетического потенциала свиней отечественного и импортного происхождения / Н.Соколов // Свиноводство. - 2007. - № 3 . - С. 5-7. 